\title{
Legal Protection of Malaysia Umrah Pilgrims
}

\author{
Wan Farahiyah Izni W Abd Rahman, Haniff Ahamat
}

\begin{abstract}
The Umrah is an Islamic pilgrimage to holy cities of Makkah and Madinah and is performed by Muslims that can be undertaken at any time of the year. Umrah travel package is a common service used by consumer in Malaysia. The high demand for this service is contributed by better conditions of the economy in Malaysia so that raising awareness of Malaysian to perform Umrah and the number of registered Umrah pilgrims continued to increase annually. There are also many complaints reported in the Tribunal for Consumer Claims in relation to this service. The aim of the article is to analyse the extent to which the relevant laws protect the rights of Umrah consumers in Malaysia. Being qualitative in nature, this study collects relevant framework which include laws, regulations and guidelines which are related to Umrah services. The purpose is to analyse the adequacy of the existing consumer protection laws in protecting Umrah pilgrims. The result of the study indicated that in Malaysia, there is no self-standing law on Umrah pilgrims' protection, though there are several laws which provide limited rights to pilgrims such as the law of contract, the law of tort, the Consumer Protection Act 1999 and the Tourism Industry Act 1992. The existing laws are inadequate to provide a comprehensive protection to the Umrah pilgrims. This article proves that there are many hindrances under the law of contract and the law of tort for Umrah pilgrims to seek for remedies. In addition, there exist lacunae and ambiguity in the statutory provisions under the Consumer Protection Act 1999 and Tourism Industry Act 1992 which need further amendments. This study proposes improvement to the existing laws so that it will be able to provide adequate protection to the Umrah pilgrims.
\end{abstract}

Index Terms: Consumer Protection, Malaysia, Pilgrims, Umrah.

\section{INTRODUCTION}

Malaysia is a Muslim majority country and more than $60 \%$ of its population comprises of Muslims [1]. The five pillar of Islam are foundation of a Muslim life and they are religious duties expected for every Muslim. The five pillar of Islam are the testimony of faith, prayer, giving Zakat (support of the needy), fasting during the month of Ramadhan and the pilgrimage to Makkah [2]. There are two types of pilgrimage in Islam which are Hajj and Umrah. Hajj and Umrah are the types of pilgrimage that are made obligatory in the Quran based on the following verse, "And complete the Hajj and Umrah for Allah". [3] Every individual Muslim is obliged to perform the Hajj at least once in a lifetime [4] - [6]. However, he or she can choose to perform it several times if he or she is physically and financially able. In contrast to the Hajj which has specific dates according to the Islamic lunar calendar, the journey of Umrah is an Islamic pilgrimage to Makkah, performed by Muslims that can be undertaken at any time of the year [7].

Revised Manuscript Received on April 19, 2019.

Wan Farahiyah Izni W Abd Rahman, Faculty of Law, Universiti Kebangsaan Malaysia, Bangi, Selangor, 43600, Malaysia.

Haniff Ahamat, Faculty of Law, Universiti Kebangsaan Malaysia, Bangi, Selangor, 43600, Malaysia
It is sometimes called the 'minor pilgrimage' or 'lesser pilgrimage' and the Hajj being the 'major pilgrimage'. The Umrah is not compulsory but highly recommended.

Umrah literally is an act of pilgrimage, but technically, it refers to an act of visiting the house of Allah (Kaabah) to perform certain act of worship including Ihram (a sacred state), Tawaf, Sa'i between Mount Safa and Marwah and Tahallul (shaving) in accordance with certain imposed conditions within a particular set of order. It has a total of five steps compared to the Hajj which have six obligatory steps. There are a number of essential acts which must be avoided once a pilgrim enters into the state of Ihram and makes the intention (Niyah). He or she must avoid the following acts, making marriage proposals or marriage contracts, cutting hair, clipping nails, putting perfumes on their body after putting on the Ihram, killing or hunting animals, sexual intercourse, shaving any parts of the body, men must not wear any underwear or cover their head or get in disputes [8]. The sole purpose of these prohibition is to focus the pilgrims' minds and body on the Umrah pilgrimage.

Umrah is one of favourable Islamic rituals in a Muslim's life where all Muslims around the world desire to perform. This ritual is not an obligatory for Muslims to perform as Hajj except for those who have the financial abilities to come to the city of Makkah and fulfill this ritual [9]. Also, Umrah can be performed anytime during the year. As travelling has become cheaper and easier, Umrah pilgrimage has become a trend. Muslims regard visiting Makkah to perform Umrah is the best way to strengthen their spiritual life. The ritual of Umrah begins when the Umrah visitors start on seeking for Umrah package that suit them according to their budgets from the travel agencies in their countries which offer Umrah services [10]. Once the Umrah visitors agree with the packages, the Umrah package contains flight, arrival, departure, transportation and accommodation.

\section{A. Umrah Industry in Malaysia}

In Malaysia, Umrah is an industry that records tremendous growth every year. The industry potential is indeed enormous and capable to grow further to generate economic prosperity for the Malaysian Muslims. The potential of this industry will never cease as demand of act of worship in performing Umrah will never be exhausted. Every year the number of Umrah pilgrims from Malaysia recorded a significant increase [11], [12]. Statistics released by the Saudi Hajj Ministry shows that in 2015, there were 202,538 Umrah pilgrims from Malaysia. In 2017, at least 250,000 Malaysian went on their Umrah and this number is 
expected to increase to 300,000 in 2018 [13]. As for 2019, there are already 185,716 number of pilgrim from Malaysia for only two months [14]. The vision of 2030 reform plan aims to attract more than two million of Malaysia Umrah pilgrims to Makkah. The quota system restricts the number of people able to perform Hajj in a year and given the long waiting period of Hajj [15] - [17], many Muslims instead opt to perform the Umrah, which can be taken at any time.

Umrah travel package is a common and regular services used by consumers. The high demand for this service is contributed by better conditions of the economy in Malaysia so that raising awareness of Malaysian to perform Umrah. Travel agency is a rapidly growing business which can provide Umrah pilgrims a variety of assistance that includes accommodation, transportation, tickets, tour packages and many more. In Malaysia, a travel agency is divided into two which are general travel agency and Hajj and Umrah travel agency. Umrah has been regulated by the Ministry of Tourism and Culture (MOTAC) under the Umrah Regulatory Council (Majlis Kawal Selia Umrah). Those travel agencies who want to sell Umrah packages need a special Umrah license issued by MOTAC. If convicted of fraud, the operators will lose their Umrah license. As in November 2017, the MOTAC has licensed 234 travel agencies which offer Umrah packages services, of which 65 are travel agencies accorded with the Muasassah (Umrah special license) while another 169 travel agencies are not accorded with the Muasassah [18].

\section{B. Fraud Umrah Package}

Umrah is an act of devotion, recommended on any capable Muslims. Umrah is also relatively easier to perform compared to Hajj as Umrah neither has restricted quotas nor time constraints. However, industry reputation became tarnished by fraud and abuse. There are three main forms of fraud that have always been complained by pilgrims in Malaysia. There are first, fraud with the intention not to conduct any service, second, service not as the same as promised and the third is other Umrah package related fraud cases such as scratch and win. Despite clear reminder by Allah, these forbidden acts of fraud and abuse still exist. "And do not consume one another's wealth unjustly or send it [in bribery] to the rulers in order that they might aid you to consume a portion of wealth of the people in sin, while you know it is unlawful" [3]. Two main reason were identified on why the statistics of Umrah fraud package is on the rise even if such fraudulent practices are strictly forbidden in deceiving and profiteering party and the second one is the weakness of the consumer themselves who fall prey to the trap of cheap Umrah packages.

There have been many consumer complaints related to Umrah service in Malaysia despite Muslims showing a great interest to perform the Umrah. MOTAC received 214 complaints involving Umrah travel fraud between 2012 to 2016. In the same period, 3,482 cases involving over RM21 million had been referred to the Tribunal for Consumer Claims (TCC) [19]. Police also received 231 complaints involving losses of more than RM9 million. The complaints include non-delivery of air tickets, failure to obtain visas for Umrah pilgrims, cancellation or postponement of the Umrah Islam. The first one is the unscrupulous greed of the

trips without prior notice or valid reasons, breach of terms and conditions as stated or promised in the package contract, reduction of the days in the Umrah trips and also services that come far differently from those advertised [20].

Newspapers had extensively covered the fraud and abuse within Umrah industry [21], [22]. The reality is that the travel agent, syndicate or third party does exist to deceive the victims with a variety of manoeuvres in order to reap the illegal profit. The syndicate's tactics were highly customized to well suit the victim and the targeted area. Some offered Umrah package with ridiculously low price, sometimes even free of charge. They claimed that their Umrah package was cheaper because it was sponsored by corporate bodies, celebrities or other uninformed sources. There were also cases where the Umrah pilgrims were left out and stranded at the airport. This syndicate promoted Umrah package via internet and the registration was only completed through online. They distributed the information through WhatsApp. This syndicate had attracted a large number of victims due to it unbelievable low price.

There are also a number of reported cases filed in the Tribunal which illustrate complaint relating to fraud Umrah package. In Mat Bin Mat Taha v Syamar Smart Venture [TCC-WP-(P)-1042-2014], the claimant filed a claim in the tribunal in Wilayah Persekutuan, Kuala Lumpur against defendant, Syamar Smart Venture. The Claimant claimed a refund of RM 7000.00 for the Umrah package which the travel agency failed to provide. The tribunal decided in favor of the claimant. Similarly, in Shahrier bin Pawanchik $v$ Madain Al Taqwa Travel \& Tour Sdn Bhd [TCC-P-(P)349-2014], the claimant made a payment of RM 11,100.00 for End-Ramadhan Umrah package for three persons including himself, his wife and a daughter. The package was cancelled by the defendant on 25 June 2014. According to the notice sent by the defendant, they agreed to refund the money within 45 days after the notice. However, no payment was made as promised. The claimant filed a case in the tribunal. The tribunal decided the defendant should pay to the claimant a total of RM 11,100.00 within 30 days from the date of award.

The increasing number of complaints against Umrah travel package confirmed the assertion that their businesses are vulnerable to fraudulent practices [23]. Cases of Malaysians becoming victims of Umrah travel fraud are not new. Like a recurrent disease, they have surfaced every year in the last 10 years. The tragedy is that although reports of such fraudulent practices are often published, the cases continue to pile. The truth and reality in many cases involving Umrah fraud package, the victim was deceived or knowingly submitting a payment without having any clear documentation. The victim handed over the payments on the basis of trust and confidence without demanding any written evidence or proof. This includes paying directly to the accounts of individuals rather than companies. Hence, the authorities face a real challenge of producing evidence before any effective action could be made as they have to act as prescribed by the act. Therefore, it is timely to study 
consumer protection issues on the Umrah services industry in Malaysia. Clear and definite legal instrument are needed to protect the rights of pilgrims as consumers of Umrah services.

\section{LITERATURE REVIEW}

\section{A. Consumer Protection}

Consumer protection covers the protection of consumer rights against any malpractice related to trade and commerce in various industries [24]. The protection may come in various forms but legal protection appears to be the most important compared to self-protection by consumers and self-regulation by traders. The development of consumer protection is aimed to provide consumer with fair and efficient complaint mechanism which empower them with the knowledge to protect themselves from trader's malpractices [25]. There is little research about the consumer protection of Umrah pilgrims in Umrah Service industry. One study has examined the legal protection against Indonesian Umrah Jemaah [26]. This study examined the need to have a clear legal instrument in Indonesia to protect the rights of pilgrims as consumers of Hajj and Umrah. Another study is on the supervision against the implementation of Umrah worship trip [27]. Supervision is done because there are many travel agencies that provide Umrah services in Indonesia, but, there are no rules and regulations that have been able to protect the consumers i.e. the Umrah pilgrims in the case of pilgrimage to Makkah. Improvement of the services and protection of all pilgrims is meant to ensure the best quality of Mabrur (perform in a manner pleasing to Allah). The high interest of Muslims to perform pilgrimage, especially in Indonesia is not supported with the quota given by the government of Saudi Arabia that creates a long queue. The number of pilgrims and the long queue of waiting list that is in turn triggered various of new problems especially regarding the lack of adequate legal protection against them [28]. The waiting listed pilgrim candidates should receive the same legal protection as a pilgrim candidate whose departure is confirmed. However, currently the protection of the pilgrims was only limited to the protection of pilgrims who are already set off for departure. Interestingly, however the existing literature has not provided a study on Malaysia perspective. Therefore, the study attempts to bridge the gap by examining the legal protection of Umrah pilgrims in Malaysia.

\section{RESEARCH METHODOLOGY}

The legal study conducted was indeed qualitative in nature. Being so, research methodologies of library research and critical analysis were used in analysing relevant materials, data and information. This legal study has collected relevant materials, data and information on Umrah service matters especially those involving pilgrims' protection issues. Figures from relevant governmental bodies such as Ministry of Tourism and Culture Malaysia and the Tribunal for Consumer Claims were critically assessed and analyzed. The approach to be applied involves a content analysis of existing laws, regulations and guidelines on the legal protection of Umrah pilgrims as consumer in Umrah travel package service. This includes an examination of relevant provisions of Malaysia Contract Act 1950, Consumer Protection Act 1999, as well as the Tourism Industry Act 1992. By doing so, an evaluation could be carried out to discover related legislation which can be applied to protect Umrah pilgrims in Malaysia.

\section{EXISTING LEGAL PROTECTION FOR UMRAH PILGRIMS}

In Malaysia, the legal protection for Umrah pilgrims can be found in various laws. As contractual relationship involves in Umrah travel package services, therefore, the Malaysia Contracts Act 1950 and the general law of tort of negligence are applicable. In addition, the main legislation that provides protection to the Umrah pilgrims in Malaysia is the Consumer Protection Act 1999. Since Umrah service are part of Islamic Religious Tourism offered by tourism industry, the Tourism Industry Act 1992 and its regulations are very relevant. The following discussion provides insight into the protection accorded to Umrah pilgrims under relevant laws.

\section{A. Protection under the Contracts Act 1950}

The law of contract is govern by the Contracts Act 1950 . In services industry, a contract is an agreement or promise made between two or more parties that the court will enforce. In other words, it is a set of rules governing the relationship, content and validity of an agreement between two or more persons. A valid contract can be considered at the moment that the offer is accepted. In Umrah service, for example, if a person has been agreed to purchase an Umrah package from a travel agent for RM6000, that is mean there is a valid contract. Once the person paid the price of the package, and the travel agent performs the act, the contract is complete. As there is a contractual transaction between the Umrah travel agent and the Umrah pilgrims, therefore, the parties involved bind by the law of contract. This is because, there are elements of offer, acceptance and consideration from the parties of the contract and there is an intention by the parties to carry out the terms of the contract as promised.

As stated in Section 2(h) of the Act, "An agreement enforceable by law is a contract". Generally, the law will only compel a person to carry out his promise if that promise is embodied in a valid contract. If a valid contract exists, then a party to the contract can sue the other for failure to carry it out. Besides that, Section 38(1) of the same act also provides about the obligation of the parties to the contract, where it was stated that "The parties to a contract must either perform or offer to perform, their respective promise, unless the performance is dispensed with or excused under this act, or of any other law". In the case of the death of one parties to the Umrah scheme contract, therefore, representative of the person will continue the contract on behalf of him. Subsection 2 of the section 38 provides, "Promises bind the representatives of the promisors in case of the death of the promisors before performance, unless a contrary intention appears from the contract. 
Furthermore, the Contracts Act 1950 also provides protection to the Umrah pilgrims against fraud. 'Fraud' includes any acts which are committed with the intention to induce another party to enter into a contract [29]. The Umrah travel agency might use deceptive statement to allure the tourist to enter into the contract. Such contract is considered to be a voidable contract. [30] refers to the Contracts Act 1950 and states that when a consent to an agreement is caused by coercion, fraud or misrepresentation, the contract is voidable at the option of the party whose consent was so caused. The agreement also becomes void if the mistake was made by both parties. Section 21 of the Contracts Act stated that: "Where both the parties to an agreement are under a mistake as to a matter of fact essential to the agreement, the agreement is void".

In addition, if the travel agent for the Umrah services fails to fulfil a condition and the innocent party terminates the contract as consequence, the Contracts Act 1950 also provides the protection to the pilgrims of the Umrah service. According to Section 40 of the Contracts Act 1950, "When a party to a contract has refused to perform, disabled himself from performing, his promise in its entirety, the promisee may put an end to the contract, unless he has signified, by words or conduct, his acquiescence in its continuance". In short, the section explains that the contract can be discharged due the failure of travel agent in providing services. However, the legal protection under the law of contract is limited only to the contracting parties [31].

Part VII of the Contracts Act 1950 explains about the consequences of breach of contract where its provide compensation for loss or damage caused by breach of contract. Section 76 of the act discuss about the right of the party to get compensation caused by the breach of the contract. It stated that, "A person who rightly rescinds a contract is entitled to compensation for any damage which he has sustained through the non-fulfillment of the contract". The Contracts Act 1950 is an act which contains the brief principles of the law of contract. Therefore, this act does not have the specific part which governs the content and terms of the contract.

\section{B. Protection under the Law of Tort}

Like a breach of contract, tort is also a civil wrong which gives rise to an action for damages. However, tort and contract are different in term of duties. The duties in tort are primarily fixed by the law, while in a contract the duties fixed by the parties themselves. In other word, the duty in tort is towards persons generally whereas in contract it is towards a specific person or persons. Tort and contract may overlap in that the same wrong may be both a breach of contract and also a breach of duty which constitutes a tort. Duty in the tort of negligence means duty as imposed by the law, or legal duty. It is only the breach of this kind of duty and its resulting damage that may give rise to liability in negligence. A duty of care exists in normal circumstances whereby if a person does not take the usual degree of precaution another person or his property may injure or damaged.

The primary principles used in determining the existence of a duty of care is the famous 'neighbour principle'. This principle was laid down in the famous case of Donoghue $v$
Stevenson [1932]. In this case, the defendant, a ginger beer manufacturer, had sold ginger beer to a retailer. A bought a bottle and entertained the plaintiff, who then drank the ginger beer. When A refilled the glass, along with the ginger beer came the decomposed remains of a snail. The plaintiff was severely ill as a consequence. The plaintiff sued the manufacturer, and claimed that the manufacturer had a duty in the course of his business, to prevent snails from entering into the ginger beer. The issue arise in this case is whether the manufacturer owed such duty to the plaintiff. The House of Lord held that the test to determine the existence of such a duty, was whether the plaintiff was the neighbour of the manufacturer.

Lord Atkin formulated the neighbour principle by stating that, "The rule that you are to love your neighbour becomes in law, you must not injure your neighbour, and the lawyer's question 'who is my neighbour' receives a restricted reply. You must take reasonable care to avoid acts or omissions which you can reasonably foresee would be likely to injure your neighbour. Who, then, in law is my neighbour? The answer seems to be persons who are so closely and directly affected by my act that I ought reasonably to have them in my contemplation as being so affected when I am directing my mind to the acts or omissions which are called in question". Applying the neighbour principle, the court held the manufacturer liable. The decision of this case created a new category of duty, owed by the manufacturer to the consumer.

The neighbour principle is an objective test in the sense the court will ask the hypothetical question, would a reasonable man, who is in the same circumstances as the manufacturer, foresee that his conduct will adversely affect the plaintiff? If the answer is no, the plaintiff is not a neighbour of the defendant and no duty of care arise. Conversely, if the answer is yes, this means that the plaintiff is a neighbour of the manufacturer and the manufacturer owes a duty of care toward the plaintiff. The word 'closely and directly affected by my act' in the quotation above does not necessarily mean close in the physical sense. 'Closely' refers to the foresight of a reasonable man who is able to foresee that the plaintiff will be affected by the defendant's act or omission. However, it is only a general rule that a plaintiff who suffers physical damage to his property will not have difficulty in establishing a duty of care. In short, a duty of care may be held to exist if the following factors are fulfilled: (a) the damage is reasonably foreseeable, (b) there is a close and direct relationship of proximity between the plaintiff and the defendant, and (c) in addition to the two requirements above, the circumstances as a whole must be such that it is just reasonable for the imposition of a duty of care.

Under the law of tort of negligence, travel agents are under a duty of care to carry out their services with all reasonable care and skill. However, [32] say that there are quite difficult in filing the case under the law of negligence because the basic element of duty of care, breach of duty and damage need to be established. Due to the limitation in 
the law of contract and tort, it is advisable for the consumer to file cases under the Consumer Protection Act 1999.

\section{Protection under the Consumer Protection Act 1999}

The Consumer Protection Act 1999 is the main statute which provides protection to Umrah pilgrims in Malaysia. Section 3 of the Consumer Protection Act 1999 defines 'services' to include any rights, benefits privileges or facilities that are or are to be provided, granted or conferred under any contract but does not include rights, benefit or privileges in the form of the supply of goods or the performance of work under a contract of services. The services of Umrah travel agency are obviously within the definition of this section. Nevertheless, if compared with the definition of services in Competition and Consumer Act 2010 (Australia) and Consumer Guarantee Act 1993 (New Zealand), Consumer Protection Act 1999 defines services broadly without mentioning any specific services as listed in these two legislation [33].

This Act also applies only where the service is supplied to a consumer. 'Consumer' in the context of supply of services is defined as a person who; (a) acquires or uses services of a kind ordinarily acquired for personal, domestic or household purpose, use or consumption; and (b) does not acquire or use the services, or hold himself out as acquiring or using the services, primarily for the purpose of (i) resupplying them in trade; (ii) consuming them in the course of a manufacturing process (Consumer Protection Act 1999, s3). It is lucid from the definition is that a consumer can either be the one who buys or uses the services The consumer is not necessarily the buyer or the contracting party [34]. This is very significant in cases of Umrah travel services because only one person deals with the travel agent on behalf of others. All of them are entitled for the protection under this act. For example, a father who booked an Umrah package for the whole family, all of them are entitled for the protection under the laws of Consumer Protection Act 1999.

Furthermore, Part II of the act deals with misleading and deceptive conduct, false representation and unfair practices [35]. This part seeks to explain the legal provision that ensure the pilgrims are not victimised by the sellers of services with misleading and false information about their services. According to section 9 of the Consumer Protection Act, no person shall engage in conduct that, "In relation to services, is misleading or deceptive, or is likely to mislead or deceive, the public as to the nature, characteristics, suitability for a purpose, or quantity, of the services". This part also explains about the criminal and civil liability imposed on the travel agents who provide misleading information about their advertise services that they did not intend to provide.

[36] illustrates about the protection of the consumer in the respect of supply of services in the form of implied guarantees. A service guarantee is a promise that a service will meet certain consumer expectations or standards. However, the word 'guarantee' is not defined in this act. Part VIII of this act provides consumer with a right to receive services that are carried out with reasonable care and skill [37]. This protection is very relevant for pilgrims who have opted for Umrah package. A failure of the travel agent to provide Umrah services as stated in their brochure is a clear breach of the guarantee. Travel agents are expected to be knowledgeable about the service they provide. Their work must be at least as good as what a competent person with average skills and experience would provide. However, according to [38], the section does not elaborate on the degree of care and skill required. The act also provides pilgrims with procedure so they can cancel the contract due to the failure or dissatisfied services that provided by Umrah travel agents, in cases of breach of guarantees. Section 60 of this act states that consumer may require the supplier to remedy the failure within reasonable time. In other words, the act provides a right to Umrah pilgrims in a way of cancellation of the contract.

The inclusion of provisions relating to a supply of services in the Consumer Protection Act 1999 is very significant in the development of law of services. In conjunction with the aim of protecting consumers against defective or ineffective services, the act creates a number of statutory implied guarantees. The act also introduces an entirely different remedial scheme for breach of the guarantees which are supposed to offer more practical remedies to consumers.

\section{Protection under the Tourism Industry Act 1992}

The main legislation that governs the tourism industry in Malaysia including Umrah services is the Tourism Industry Act 1992. The management, licensing and monitoring of the Umrah business operation is within the jurisdiction of the Ministry of Tourism and Culture Malaysia. Umrah falls under the Outbound Licensing via virtue of this act, and its regulations. To avoid fraudulent practices among Umrah travel agents, the act makes the registration of the Umrah travel agencies to be mandatory. Under the law, neither company nor any individual is allowed to operate, deal or transact the Umrah package unless they were licensed by the act. Section 5 in Part II of the act provides that the tourism enterprises need to be licensed. Thus, operating travel agency business without a license is an offence [39].

Furthermore, every person to whom a license has been issued must be a member of the Malaysian Travel and Tour Association (MATTA) or any other association of travel agencies recognized by the Commissioner [40]. There are also other associations of travel agents, namely; Malaysian Chinese Travel Association (MCTA) and Bumiputra Travel and Tour Agents Association (Bumitra) [24]. For the future development of Umrah industry, it is interesting to has a specific association for Umrah travel agencies. The Tourism Industry (Tour Operating Business and Travel Agency Business) Regulations 1992 provides the details about travel agencies services. The regulation provides the standard terms and conditions of contract between the travel and tour operators and their holidaymakers. These include matters relating to rights and duties of the agencies and the tourists, payment of deposit, cancellation and refund. However, the law is applicable for general application and there is no provision relating to Umrah services.

In addition to this act, Umrah travel agencies as well as Malaysian Umrah pilgrims are required to comply to the

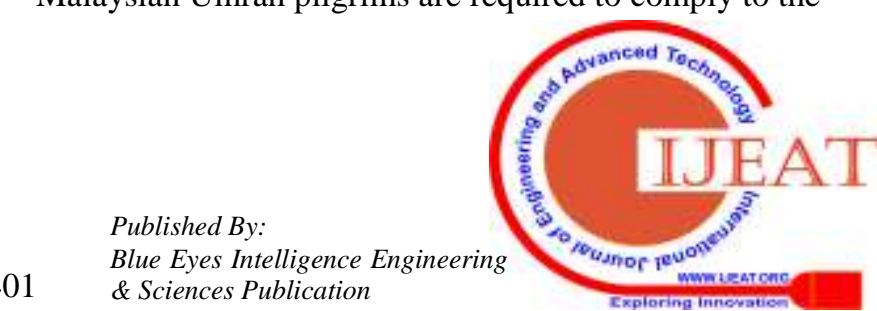


rules and regulations issued by the Government of Saudi Arabia. Starting from 2011, the Saudi Arabian Embassy in Malaysia has stopped issuing Umrah visas to any individual or company except only to those travel agencies that has signed an agreement with the company appointed by the Government of Saudi Arabia (Muasassah). In order to be appointed as Muasassah operators, Umrah travel agent need to have valid outbound license as well as depositing security deposit to the Government of Saudi Arabia.

At present, although Umrah is an Ibadah (Act of devotion) in Islam, however, there are no specific religious authorities to regulate the affairs of Umrah. The management of Umrah in Malaysia is governed across various agencies with the main responsibilities lies under Ministry of Tourism and Culture via the provision of the act. As on August 2014, the government has established Umrah Regulatory Council (MKSU) in order to effectively address the Umrah fraud issues. MKSU was established to focus on the controlling the Umrah operation and eradicating fraud Umrah by imposing a special license for Umrah travel companies. MKSU has also set a minimum indicator prices to determine the validity of an Umrah package. Any donation obtained to reduce the price of the package requires notification to MOTAC. As a member of MKSU, Jabatan Wakaf, Zakat \& Haji, Malaysia (JAWHAR), has developed an i-Umrah portal to view the list of Muasassah companies. However, the misperception that Umrah is under a religious body has cause Malaysians to inaccurately channel their complaints related to Umrah affairs. It appears that many Malaysian were under the impression that Tabung Haji is the sole authority to conduct the Umrah's matter. However, this is inaccurate as Tabung Haji's scope does not cover Umrah's affairs. Tabung haji is only resposible for the affair of hajj, fund administration of the pilgrims' welfare, as contained in the Lembaga Tabung Haji Act 1995.

The existing rules under this act have limitation and constraints. This is because it only accounts for control and monitoring in Malaysia whereas the monitoring and enforcement in Makkah are not governed by Tourism Industry Act 1992 jurisdiction as it is under the jurisdiction of the Saudi Arabia. In addition, Umrah is an act of devotion and MOTAC is not the religious authority that has its networks of cooperation with Saudi Arabia to monitor the Umrah activities and the performance of Umrah travel agencies in Makkah. As the main purpose of the Tourism Industry Act 1992 is to ensure that all Umrah related travel agent to register their business and be licensed, therefore the Ministry of Tourism and Culture of Malaysia could only take action against fraudulent agents especially Umrah operating agencies that are licensed or unlicensed on the existing provisions under this act, including compounds on the offenders. The Ministry of Tourism and Culture also has no jurisdiction to investigate on fake agents providing fraudulent Umrah packages. The investigations have been said to be under the jurisdiction of Royal Malaysia Police. It is because such offences were a crime under the Penal Code.

\section{E. Redress Mechanism}

Despite all the efforts by all parties to uphold their promise and responsibility in ensuring the smooth running of Umrah affairs, certainly there will a fraction of an event that result in the dispute and conflict. Among the rights of the consumers that have been prescribed by the Consumer International is the right to get redress. There is various mechanism for the Umrah pilgrims to complaint for their problems and to settle their dispute with travel agents [41]. The rights, however, are worthless in the absence of an effective redress mechanism which is suitable, practicable and inexpensive to enforce. [42] stated that the most important elements for the redress mechanism are the ability to solve Umrah pilgrims' complaint efficiently and with minimum cost.

Tribunal for Consumer Claims is the main redress centre in Malaysia and its primary function is to hear and determine claims filed by pilgrims [26]. Tribunal for consumer claims is an independent judicial bodies established under part XII of the Consumer Protection Act 1999. Section 85 of the Consumer Protection Act 1999 provides "There shall be a tribunal to be known as the Tribunal for Consumer Claims'. It aims to overcome the failure of the court system in providing redress which is proven to be expensive, complex and worrisome. It was set up as a simple, fast and cheap alternative channel for consumer to claim losses not exceeding RM25,000 [37]. If the claim exceeds the limit, the consumer has to abandon the exceed limit and the Umrah travel agent will be discharged from liability in respect of the abandoned amount [37]. Thus, the consumer cannot later bring action to claim for the exceeded amount. The provision clearly deprives the consumer rights by asking them to sacrifice in order to bring the complaints within the jurisdiction of the tribunal.

The tribunal's jurisdiction also covers any claim in respect of any services for which no redress mechanism is provided for under any other written law and based on a cause of action which accrues within three years of the claim. The tribunal has received quite a lot of response from Umrah pilgrims, but yet there are many improvements to be made. The tribunal has a lack of power to enforce the awards and accessibility [43]. To be able to function more efficiently, the current weaknesses of the tribunal must be remedied. The tribunal has two methods of resolving the disputes, namely, by an assisting the parties to negotiate and agreed settlement or by conducting a proper trial. According to section 107 of the Consumer Protection Act 1999, "The tribunal shall, as regards every claim within its jurisdiction, assess whether, in all the circumstances, it is appropriate for the tribunal to assist the parties to negotiate an agreed settlement in relation to the claim". This provision places the tribunal in a different category from the courts usually rely upon adjudicatory procedures. Nevertheless, there is also ambiguity in respect of the negotiation process in which there are no clear guidelines on how it is to be carried out.

Complaint Management Unit and Community Services, under the Ministry of Tourism and Culture Malaysia is another redress centre where the Umrah pilgrims can file their complaint. The function of the unit is to manage and monitor all complaints from Umrah pilgrims through various medium of communication. It also analyse tourism 
related issues which are advertised in the mass media. Furthermore, the centre also performs as an agent in preparing responses to complaints and recommends proper action to be taken. Umrah pilgrims may also file a complaint relating to unsatisfactory services by travel agent and undelivered promises at the National Consumer Complaint Centre. The National Consumer Complaints Centre is a nonprofit organization managed by Federation of Malaysians Consumer Associations (FOMCA). The Centre provides a mechanism for consumer complaints and counselling to resolve problem arising from the purchase of services. In addition, the centre also provides Umrah pilgrims with information on consumer related matters and voices out consumers concerns in the media. Nevertheless, it is discovered that the remedial scheme is hampered by many limitations and is not necessarily more favourable to the consumer in all cases.

Based on the above discussion, we can clearly question the rights of Umrah pilgrims for the present laws are deemed inadequate in curtailing the fraudulent package of Umrah travel agents and consequently depriving and cheating the Muslims of Umrah packages.

\section{CONCLUSION}

The growth in the Malaysia Muslim economy had led to a large number of pilgrims performing Umrah annually. Travelling cost and ease of the travelling process also have resulted in a significant increase in the number of Umrah pilgrims. The study reveals that there are a number of existing laws which can be applied to protect the Umrah pilgrims in Malaysia. However, the increasing number of complaints against Umrah packages provided by the travel agencies is an alarming indicator that the existing laws are inadequate. Existing act and regulations are not fully effective to eradicate the fraud. It has become the obligation of the government to protect the Umrah pilgrims from any form of cheating by travel agencies. Therefore, it is imperative for the government to ensure that the current laws are fully enforced and if there are loopholes in those laws, reviews and amendments must be made. This would ensure a set of laws that is effective for the optimization of Umrah pilgrims protection to its utmost level. It is desirable that a clear and definite legal instrument to be in place to balance between supporting the growth of the sector and for protecting the pilgrims as consumers of Umrah services. Subsequently, to ensure that Umrah pilgrims right are safeguarded, especially in the context of Umrah travel packages, all parties involved namely, the government, consumer associations, NGO's, travel agencies and Umrah pilgrims themselves, must play a role to ensure that the misappropriations of travel agencies conduct can be curtailed while preserving the right of Umrah pilgrims.

\section{REFERENCES}

1. Department of Statistic M. Population distribution and basic demographic characteristic report 2010, 2015 [Available from:https://www.dosm.gov.my/v1/index.phpr=column/c theme\&menu_id.
2. n.a. What are the five pillar of Islam? Islam Guide, n.d [Available from: https://www.islamguide.com/ch3$\underline{16 . h t m}$.

3. The Qur'an

4. Ahmed ZU. Islamic pilgrimage (Hajj) to Ka'aba in Makkah (Saudi Arabia): An important international tourism activity. Journal of Tourism Studies. 1992;3(1):35-43.

5. Raj RA, Morpeth N. Case study 1: The festival of sacrifice and travellers to the city of heaven (Makkah). Religious Tourism and Pilgrimage Festivals Management: An International Perspective. 2007:127-39.

6. Al-Hashedi AH, Arshad MR, Baharudin AS, Mohamed HH. RFID applications in Hajj management system. In 2013 IEEE International Conference on RFIDTechnologies and Applications (RFID-TA) 2013 Sep 4 (pp. 1-6). IEEE.

7. Burns P. From Hajj to hedonism? Paradoxes of developing tourism in Saudi Arabia. Tourism in the Middle East: Continuity, change and transformation. 2007:215-36.

8. Mamdouh NM. Hajj \& Umrah from A to Z. Riyadh: Dar Eshbelia; 1999.

9. Gannon MJ, Baxter IW, Collinson E, Curran R, Farrington T, Glasgow S, Godsman EM, Gori K, Jack GR, Lochrie S, Maxwell-Stuart R. Travelling for Umrah: destination attributes, destination image, and post-travel intentions. The Service Industries Journal. 2017 Jun 11;37(7-8):448-65.

10. Ashdaq M, Maupa H, Amar MY, Nursyamsi I. Analysis of service quality on pilgrims satisfaction and image of Hajj and Umrah travel agents in South Sulawesi Province, Indonesia. International Journal of Research in Social Sciences. 2015 Aug;5(6).

11. Jafari J, Scott N. Muslim world and its tourisms. Annals of Tourism Research. 2014 Jan 1; 44:1-9.

12. Oktora K, Achyar A. The effect of post-purchase perceived-value towards the relationship quality of Hajj and Umrah travel agencies in Indonesia. The South East Asian Journal of Management. 2014 May 5.

13. Nabihah H. Beef up Umrah licence rather than impose fee says tour agencies group, The Malaysiam Insight, 2017 [Available from: https://www.themalaysianinsight.com/s/2804.9.

14. n.a. Ministry: More than 3.8 million Umrah visas issued so far. Arab News. 2019.

15. Timothy DJ, Iverson T. Tourism and Islam consideration of culture and duty In: Timothy, editor. Tourism, Religion and Spiritual Journeys. London: Routledge; 2006. p. 186-205.

16. Bianchi R. Reimagining the Hajj. Social Sciences. 2017 Jun;6(2):36

17. Utomo SB, Scott, N and Jin, X. The business of Hajj In: Almuhrzi, editor. Tourism in the Arab World: An Industry Perspective Bristol: Channel View Publications; 2017. p. 207-216.

18. Fauziah I. Be vigilant before signing Umrah package New Straits Times 2018.

19. n.a. Check status of Umrah operators before accepting package: Jawhar. The Sun Daily 2017.

20. Norni M. 967 charged over fraud Umrah packages. Borneo Post. 2017.

21. Hidir R. Felda folk lodge police report following RM300,000 Umrah fraud. New Straits Times. 2017.

22. Kumar M. Women arrested for cheating RM4 million in Umrah scam The Star Online. 2018.

23. Abdullah NC. Travel consumer fraud: Comparative 
analysis on regulatory framework and legal redress in selected countries. [Presentation Slide]. In press n.d.

24. Butnaru GI, Ion LM. Problem of consumer protection in tourism. CES Working Papers; n.d.

25. Sabri MF. The development of consumer protection policies in Malaysia. International Journal of Business and Social Research 2014;4(6).

26. Maggalatung S. Legal protection against Indonesian Umrah jemaah. Jurnal Cita Hukum. 2017 Jun 16;5(1).

27. Putra A. Pengawasan terhadap penyelenggaraan perjalanan ibadah Umrah (Studi terhadap kasus PT. Firs Anugerah Karya Wisata), Jurnal Nestor Magister Hukum 2018;1(1).

28. Mariani; Luth, Thorhir; Muhjad, M. Hadin; Fadli, Moh. The administration of the waiting listed pilgrim candidates in a justicial operation system of Hajj worship. JL Pol'y \& Globalization. 2016; 49:62.

29. Contracts Act, (1950).

30. Abdullah NC. General principles of Malaysian law: with special reference to the travel and tourism industry. Pusat Penerbitan Universiti, Universiti Teknologi MARA; 2002.

31. Isa SM, Aziz AA, Yusoff SS. Undang-undang kontrak Malaysia: Keterbatasan pemakaian dalam kontrak pengguna. Jurnal Pengurusan. $2011 \mathrm{Jul} ; 32: 39-53$.

32. Gan JE, Goh HH. Hospitality law. Shah Alam: Oxford Fajar Sdn Bhd; 2014.

33. Bakar EA, Amin N. Consumer protection in the service industry under the Consumer Protection Act 1999. Malaysian Consumer Law Journal. 2011 1:123-42.

34. Rahman NA, Amin N. Ahamat H. The interface between Competition Law and Consumer Protection: A Malaysian perspective. Australian Journal of Basic and Applied Science 2014;8(16).

35. Ismail R, Yusoff SS, Suhor S, Aziz AA, Razman MR, Khalid KA. A comparative study on the consumer protection legislations of Malaysia and Thailand. Social Sciences. 2012;7(2):177-88.

36. Amin N. Guarantees in a contract of supply of service to consumer. IIUM Law Journal. 2002;10(57).

37. Consumer Protection Act, (1999).

38. Bakar EA, Amin N. Consumer protection in the supply of service: A comparative study between the Consumer Protection Act 1999 Islamic Law. IIUM Law Journal. 2010;18(1).

39. Tourism Industry Act, (1992)

40. Tourism Industry (Tour Operating Business and Travel Agency Business) Regulations, (1992).

41. Yusoff SS. Perlindungan pengguna di bawah undangundang: pembekalan barang \& perkhidmatan. Jurnal Undang-undang dan Masyarakat. 2008 Jan 1;12:48-73.

42. Amin N. Consumer redress mechanisms in Malaysia: Prospects and challenges. IIUM Law Journal. 2007;15(2).

43. Bakar EA, Amin N. ADR for consumers: An appraisal of the tribunal for consumer claims Malaysia. In: Naqib M, editor. Mediation in Malaysia: The Law and Practice Kuala Lumpur: Lexis Nexis; 2010. p. 171-82

\section{AUTHORS PROFILE}

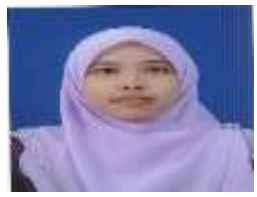

Wan Farahiyah Izni W Abd Rahman holds a bachelor of Syariah and Laws with Honours from Universiti Sains Islam Malaysia (USIM) in 2012. Then in 2013 she completed her Masters of Law at Universiti Kebangsaan Malaysia (UKM). Her research interests are Islamic Religious Tourism, Hajj and Umrah, Consumer Protection, Hospitality and Tourism Law. Currently she is now pursuing her $\mathrm{PhD}$ in the area of Islamic Religious Tourism in Universiti Kebangsaan Malaysia (UKM).

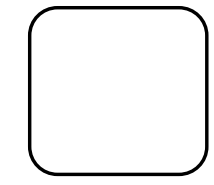

Haniff Ahamat, PhD, is an associate professor at the Faculty of Law, the National University of Malaysia (UKM). He is also currently holds the position of Deputy Legal Adviser of the same university. He has been with UKM since June 2016. Prior to that, he had been an academic staff member at the Faculty of Law, the International Islamic University Malaysia (IIUM) for 15 years. He holds an LLB (Hons) from IIUM, an LLM from UKM and a PhD from University of Essex, United Kingdom. He wrote his $\mathrm{PhD}$ thesis on the consumer perspectives of Malaysian and EC anti-dumping regimes 